Article

\title{
Quantitative Assessment of the Relative Impacts of Land Use and Climate Change on the Key Ecosystem Services in the Hengduan Mountain Region, China
}

\author{
Erfu Dai ${ }^{1,2}$, Le Yin ${ }^{2,3, *}$, Yahui Wang ${ }^{1,2} \mathbb{1}$, Liang Ma ${ }^{1,2}$ and Miao Tong ${ }^{1,2}$ \\ 1 Lhasa Plateau Ecosystem Research Station, Key Laboratory of Ecosystem Network Observation and \\ Modeling, Institute of Geographic Sciences and Natural Resources Research, Chinese Academy of Sciences, \\ Beijing 100101, China; daief@igsnrr.ac.cn (E.D.); wangyah.15b@igsnrr.ac.cn (Y.W.); \\ maliang.16b@igsnrr.ac.cn (L.M.); tongm.17b@igsnrr.ac.cn (M.T.) \\ 2 University of Chinese Academy of Sciences, Beijing 100049, China \\ 3 Key Laboratory of Land Surface Pattern and Simulation, Institute of Geographic Sciences and Natural \\ Resources Research, Chinese Academy of Sciences, Beijing 100101, China \\ * Correspondence: yinl.16b@igsnrr.ac.cn
}

Received: 17 April 2020; Accepted: 13 May 2020; Published: 17 May 2020

\begin{abstract}
In the Hengduan Mountain region, soil erosion is the most serious ecological environmental problem. Understanding the impact mechanism of water yield and soil erosion is essential to optimize ecosystem management and improve ecosystem services. This study used the Integrated Valuation of Ecosystem Services and Tradeoffs (InVEST) and Revised Universal Soil Loss Equation (RUSLE) models to separate the relative contributions of land use and climate change to water yield and soil erosion. The results revealed that: (1) Although soil and water conservation has been strengthened in the past 25 years, both water yield and soil erosion increased from 2010 to 2015 due to the conversion of woodland to grassland, which indicates that continuous benefits after the implementation of ecological restoration projects were not obtained; (2) Climate change played a decisive role in water yield and soil erosion changes in the Hengduan Mountain region from 1990 to 2015, and soil erosion was not only related to the amount of precipitation but also closely related to precipitation intensity; (3) The contribution of land use and climate change to water yield was $26.94 \%$ and $73.06 \%$, while for soil erosion, the contribution of land use and climate change was $16.23 \%$ and $83.77 \%$, respectively.
\end{abstract}

Keywords: water yield; soil erosion; land use change; climate change; relative contribution

\section{Introduction}

Ecosystem services are important factors that guarantee human survival and development [1]. Understanding the driving mechanisms of the key ecosystem services is vital for the sustainable management of ecosystems and natural capital [2,3]. Ecosystem services are closely related to topography, land use, soil, biology, climate, and socio-economic factors [4]. Land use and climate change are considered to be the main driving forces of changes in ecosystem services [5,6]. Climate change determines the spatial and temporal distribution of ecosystem services, while land use change affects ecosystem services by changing the ecosystem structure and function [7].

The results of the millennium ecosystem assessment showed that over $60 \%$ of the world's ecosystems were degrading [4]. In order to reduce the negative impact of global environmental change, it is essential to strengthen the research on ecosystem service-driven mechanisms. At present, the research methods to determine the ecosystem services' response to impact factors mainly include correlation analysis [8], regression analysis [9], principal component analysis [10], sensitivity analysis [11], geo-detectors [12], and spatial panel models [13]. However, these methods can only explore the impact 
of a single factor on ecosystem services. Few studies have focused on separating the relative impacts of land use and climate change. Comparing the simulation results under different conditions provides an effective method to distinguish the impact factors on ecosystem services [14-16]. Ecosystem service assessment models such as Integrated Valuation of Ecosystem Services and Tradeoffs (InVEST) [6], Revised Wind Erosion Equation (RWEQ) [17], and Soil and Water Assessment Tool (SWAT) [18] provide effective methods for calculating the relative contribution of land use and climate change [19-21]. In addition, compared to urban ecosystems, researchers have paid less attention to mountain ecosystem.

The Hengduan Mountain region is an important ecological function area in China. The runoff and hydraulic resources account for $10.9 \%$ and $24 \%$ of the total water resources in China, respectively [22]. However, due to intense anthropogenic disturbance (vegetation destruction, overgrazing, and sloping land reclamation), the ecological environment has been severely damaged. Annual soil erosion in the Hengduan Mountain region has reached $8.9 \times 10^{8} \mathrm{t}$, and it is one of the areas that has experienced the most severe soil erosion in China [23]. A series of ecological restoration projects were carried out in the Hengduan Mountain region, aiming to strengthen the capacity of soil and water conservation [24,25]. Therefore, water yield and soil erosion were selected to explore the driving mechanisms of ecosystem services in the Hengduan Mountain region.

The objectives of this study are to: (1) Identify and assess the key ecosystem services from 1990 to 2015 and analyze their spatio-temporal variation characteristics; (2) Separate the relative impacts of land use and climate change on water yield and soil erosion; (3) Propose improvement measures for soil and water conservation in the Hengduan Mountain region.

\section{Materials and Methods}

\subsection{Study Area}

The Hengduan Mountain region $\left(24^{\circ} 29^{\prime}-33^{\circ} 43^{\prime} \mathrm{N}, 97^{\circ} 10^{\prime}-104^{\circ} 25^{\prime} \mathrm{E}\right)$ is located in the southwest of China and is named for its complex terrain [26]. The total area of the Hengduan Mountain region is approximately $450,000 \mathrm{~km}^{2}$, and the elevation is $302 \mathrm{~m}$ to $7143 \mathrm{~m}$. The regional temperature varies greatly, with an annual mean temperature of $5^{\circ} \mathrm{C}$ to $13^{\circ} \mathrm{C}$. The annual total precipitation is $500 \mathrm{~mm}$ to $1000 \mathrm{~mm}$, with $60 \%-90 \%$ of the precipitation concentrated from May to October [27]. The main land use types are woodland, grassland, and cropland, accounting for $46.00 \%, 41.56 \%$, and $7.52 \%$ of the total area (2015), respectively (Figure 1). 

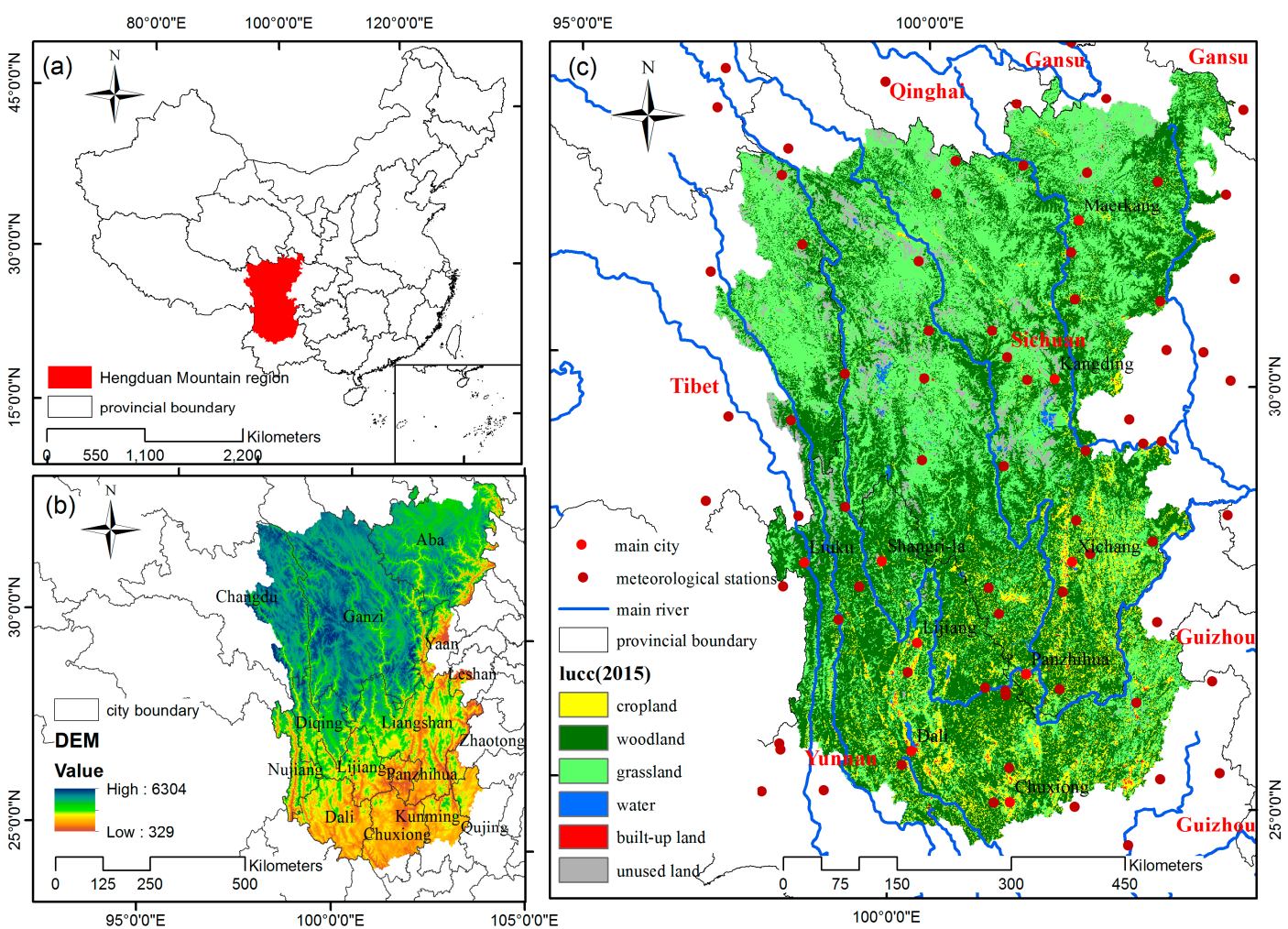

Figure 1. (a) Location, (b) Digital Elevation Model (DEM), and (c) land use types in the study area.

\subsection{Data Preparation}

\subsubsection{Land Use Data}

The land use data for the Hengduan Mountain region in 1990, 2000, 2010, and 2015 were derived from the Resource and Environment Data Cloud Platform. These datasets were based on Landsat TM/ETM remote sensing images and generated by manual visual interpretation [28]. All land use data in this study were converted to $1 \mathrm{~km}$ resolution.

\subsubsection{Climate Data}

Climate data during the period 1990-2015 were derived from the National Meteorological Information Center. This study collected data from 75 meteorological stations in or around the study area and interpolated them to $1 \mathrm{~km}$ resolution using the ANUSPLIN 42 software developed by the Australian National University to generate the raster data required for the InVEST model [29]. Based on the interpolated climate data, the potential evapotranspiration $\left(\mathrm{ET}_{0}\right)$ and rainfall erosivity for water yield and soil erosion were calculated. To better represent the average climate condition of the four study periods and avoid the randomly abnormal climate of one specific year, the climate conditions of 1990, 2000, 2010, and 2015 was replaced by the average condition in their adjacent years. For example, the annual average temperature and annual total precipitation of the Hengduan Mountain region from 1998 to 2002 were taken as the annual average temperature and annual total precipitation in 2000.

\subsubsection{Soil Data}

The soil data was obtained from the Harmonized World Soil Database (HWSD), and the plant available water content and soil erodibility were calculated based on the soil texture properties. 


\subsubsection{DEM Data}

Given that soil erosion in mountainous areas is sensitive to topographic factors, $90 \mathrm{~m}$ resolution DEM data were selected to calculate the slope and length factors in this study. The sub-watersheds were also divided by the DEM data based on the ArcGIS 10.2 platform.

\subsection{Detecting the Relative Impacts Of Land Use and Climate Change on Ecosystem Services}

This study proposes a framework for quantitative evaluation of the impact factors of ecosystem services (Figure 2). Based on remote sensing, meteorology, soil, and DEM data, we first assessed the water yield and soil erosion and analyzed their temporal and spatial dynamics. Then, we separated the relative impacts of land use and climate change on water yield and soil erosion by setting different conditions. Finally, based on the research results, we proposed management strategies to improve regional soil and water conservation capacity in the Hengduan Mountain region.

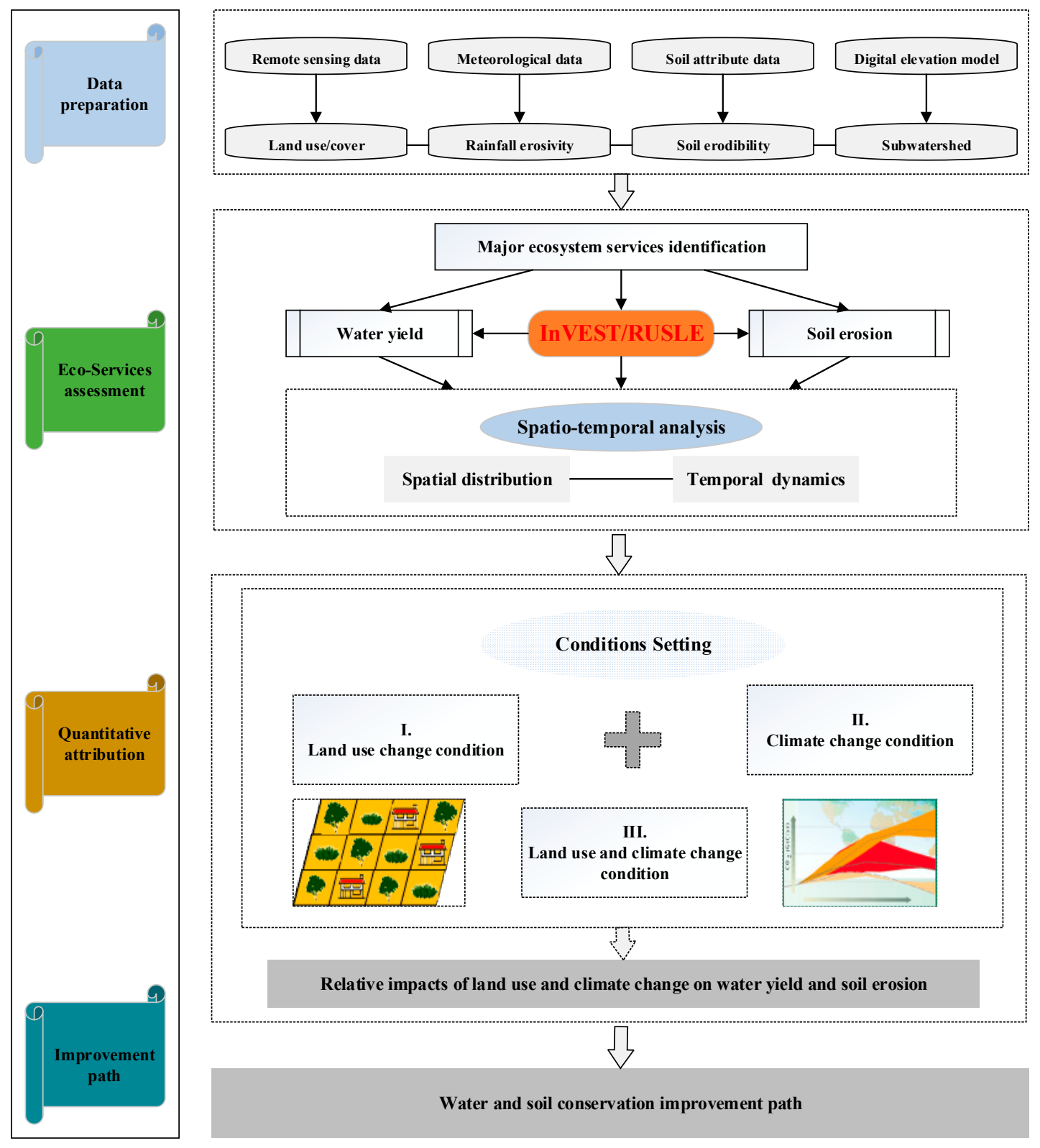

Figure 2. Framework of methodology. 


\subsection{Ecosystem Service Assessment}

The InVEST model can not only quantify ecosystem services, but also spatialize the assessment results. Currently, the model can be used to evaluate 18 ecosystem services in freshwater, marine, and terrestrial ecosystems [30]. Because this study focuses on the inter-annual variation of ecosystem services, and the data required by the water yield module are easy to obtain, the InVEST model has been selected to assess the water yield in the Hengduan Mountain region. The Revised Universal Soil Loss Equation (RUSLE) model is applicable to soil erosion simulation at different scales and compensates for the limitations of large-scale field observation [31]. Therefore, this study selected the InVEST model and the RUSLE model to assess water yield and soil erosion.

\subsubsection{Water Yield}

The InVEST model simulates water yield on a pixel scale by calculating the difference between precipitation and actual evaporation [30]. The formula is as follows:

$$
\begin{gathered}
\mathrm{Y}(\mathrm{x})=\left(1-\frac{\operatorname{AET}(\mathrm{x})}{P(x)}\right) \cdot \mathrm{P}(\mathrm{x}) \\
\frac{\mathrm{AET}(\mathrm{x})}{\mathrm{P}(\mathrm{x})}=1+\frac{\mathrm{PET}(\mathrm{x})}{\mathrm{P}(\mathrm{x})}-\left[1+\left(\frac{\operatorname{PET}(\mathrm{x})}{\mathrm{P}(\mathrm{x})}\right)^{\omega}\right]^{\frac{1}{\omega}} \\
\omega(\mathrm{x})=\mathrm{Z} \cdot \frac{\mathrm{AWC}(\mathrm{x})}{\mathrm{P}(\mathrm{x})} \\
\mathrm{R}(\mathrm{x})=\mathrm{k}(\mathrm{x}) \cdot \frac{\mathrm{ET}_{0}}{\mathrm{P}_{\mathrm{x}}}
\end{gathered}
$$

where $Y(x)$ denotes the annual water yield $(\mathrm{mm})$; AET( $\mathrm{x})$ denotes the annual mean actual evapotranspiration $(\mathrm{mm}) ; \mathrm{P}(\mathrm{x})$ denotes the annual mean precipitation $(\mathrm{mm}) ; \mathrm{R}(\mathrm{x})$ denotes the Budyko aridity index; $\mathrm{ET}_{0}$ denotes the potential evapotranspiration $(\mathrm{mm}) ; \mathrm{AWC}(\mathrm{x})$ denotes the plant available water content $(\mathrm{mm})$, determined by soil depth and physicochemical properties; $\omega(\mathrm{x})$ denotes an empirical parameter; $\mathrm{k}(\mathrm{x})$ denotes the vegetation evapotranspiration; and $\mathrm{Z}$ denotes a seasonal rainfall factor.

AWC was calculated from the soil texture [32]; $\mathrm{k}(\mathrm{x})$ was obtained from the irrigation and horticulture handbooks of Food and Agriculture Organization of the United Nations (FAO); the $\mathrm{ET}_{0}$ was calculated by the modified Hargreaves equation [33,34]; and $\mathrm{Z}$ used a default value.

\subsubsection{Soil Erosion}

We calculated the soil erosion rates for each grid using the RUSLE model. The formula is as follows:

$$
\mathrm{SE}=\mathrm{R} \times \mathrm{K} \times \mathrm{L} \times \mathrm{S} \times \mathrm{C} \times \mathrm{P}
$$

where SE denotes the annual soil erosion rate $\left(\mathrm{t} \mathrm{ha}^{-1} \mathrm{yr}^{-1}\right)$; $\mathrm{R}$ denotes the rainfall erosivity (MJ $\mathrm{mm} \mathrm{ha}^{-1}$ $\mathrm{h}^{-1} \mathrm{yr}^{-1}$ ); $\mathrm{K}$ denotes the soil erodibility ( $\mathrm{t} \mathrm{ha} \mathrm{h} \mathrm{MJ}^{-1} \mathrm{~mm}^{-1} \mathrm{ha}^{-1}$ ); LS denotes the slope length-steepness; $\mathrm{C}$ denotes the cover management; and $\mathrm{P}$ denotes the erosion control practice.

The rainfall erosivity factor $R$ was calculated as follows [35,36]:

$$
\mathrm{R}=\sum_{\mathrm{i}=1}^{12} 1.735 \times 10^{\left(1.5 \log _{10}\left(\frac{\mathrm{P}_{\mathrm{i}}^{2}}{\mathrm{P}}\right)-0.8188\right)}
$$

where $P_{i}$ denotes the monthly rainfall $(\mathrm{mm})$ and $P$ denotes the annual rainfall $(\mathrm{mm})$. 
The approach to calculate soil erosivity factor $\mathrm{K}$ is as follows [37]:

$$
\begin{gathered}
K=\left\{0.2+0.3 e^{\left[-0.0256 S A N\left(1-\frac{S L}{100}\right)\right]} \times\left(\frac{S I L}{C L A+S I L}\right)^{0.3} \times\left[1-\frac{0.25 C}{C+e^{3.72-2.95 C}}\right]\right. \\
\times\left[1-\frac{0.7 S N}{\left.\left.S N+e^{-5.51+22.9 S N}\right]\right\} \times 0.1317}\right.
\end{gathered}
$$

where $\mathrm{K}$ denotes the soil erodibility factor $\left(\mathrm{t}\right.$ ha h ha $\left.{ }^{-1} \mathrm{MJ}^{-1} \mathrm{~mm}^{-1}\right)$, SAN denotes the sand fraction (\%), SIL denotes the silt fraction (\%), CLA denotes the clay fraction (\%), and C denotes the organic carbon fraction $(\%)$. SN $=(100-\mathrm{SAN}) / 100$; the value 0.1317 is the unit conversion coefficient.

The LS was calculated as follows [38,39]:

$$
\begin{gathered}
\mathrm{S}=10.8 \times \sin \theta+0.03(\theta\langle 9 \%,\rangle \lambda>4.6 \mathrm{~m}) \\
\mathrm{S}=10.8 \times \sin \theta-0.50(\theta \geq 9 \%, \lambda>4.6 \mathrm{~m}) \\
\mathrm{S}=3.0 \times(\sin \theta)^{0.8}+0.56(\lambda \leq 4.6 \mathrm{~m}) \\
\mathrm{L}=\left(\frac{\lambda}{22.13}\right)^{\alpha} \\
\alpha=\left(\frac{\beta}{\beta+1}\right) \\
\beta=\frac{\sin \theta}{3 \times(\sin \theta)^{0.8}+0.56}
\end{gathered}
$$

where $\theta$ denotes the slope, $\lambda$ denotes the slope length, $\alpha$ denotes the length-slope exponent, and $\beta$ denotes a factor relative to slope gradient.

$\mathrm{C}$ is the ratio of soil loss under a particular crop or vegetation cover to the soil loss from the fallow land. $\mathrm{P}$ is the ratio of soil loss with soil and water conservation measures to the soil loss with slope tillage. Factors $C$ and $P$ are available through the RUSLE handbook, published by the United States Department of Agriculture [40]. This study also referred to existing research results to determine the values of factors $C$ and $P[41,42]$.

\subsection{Conditions Setting}

In this study, we set up three conditions and used the ecological models to separate the relative impacts of land use and climate change on water yield and soil erosion [43] (Table 1). Under the land use and climate change condition, both land use and climate data were input into the model according to the actual situation. Under the land use change condition, the climate was the same as that in 1990, and 2015 land use data were input into the model. Under the climate change condition, the land use was the same as that in 1990, and the climate data of 2015 were input into the model.

Table 1. Conditions setting.

\begin{tabular}{cccc}
\hline \multirow{2}{*}{ Year } & $\begin{array}{c}\text { Land Use Change + Climate } \\
\text { Change Condition }\end{array}$ & $\begin{array}{c}\text { Land Use Change } \\
\text { Condition }\end{array}$ & $\begin{array}{c}\text { Climate Change } \\
\text { Condition }\end{array}$ \\
\hline \multirow{2}{*}{1990} & 1990 land use data & 1990 land use data & 1990 land use data \\
& 1990 climate data & 1990 climate data & 1990 climate data \\
\hline \multirow{2}{*}{2015} & 2015 land use data & 2015 land use data & 1990 land use data \\
& 2015 climate data & 1990 climate data & 2015 climate data \\
\hline
\end{tabular}




\section{Results}

\subsection{Driving Forces Analysis of Water Yield and Soil Erosion}

\subsubsection{Land Use Change Analysis}

Affected by the implementation of ecological restoration projects, woodland and grassland were frequently interconverted, while cropland, water bodies, built-up land, and unused land only slightly changed. The increase of woodland was mainly caused by the conversion of grassland, among which the woodland increased by $4560 \mathrm{~km}^{2}$ and the grassland decreased by $4113 \mathrm{~km}^{2}$. Moreover, both woodland and grassland changed from low to high coverage. The cropland and unused land decreased by $768 \mathrm{~km}^{2}$ and $649 \mathrm{~km}^{2}$, respectively, and were mainly converted to grassland and woodland. Cropland was converted to built-up land, which increased by $764 \mathrm{~km}^{2}$. There was little fluctuation in water body areas. The characteristics of land use conversion were different in each period, with the period from 2000 to 2010 being the most dramatic period of land use change (Figure 3).

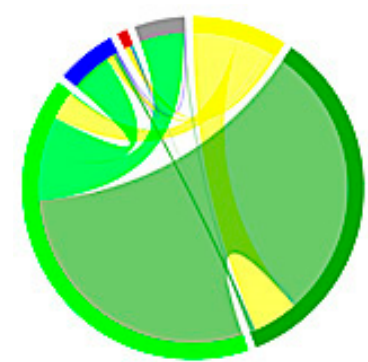

1990-2000

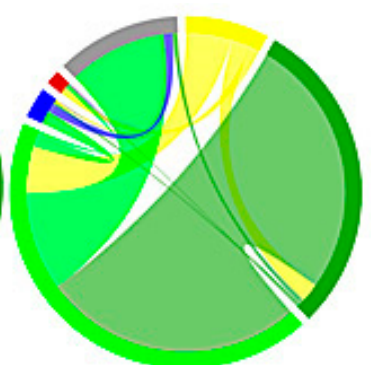

2000-2010

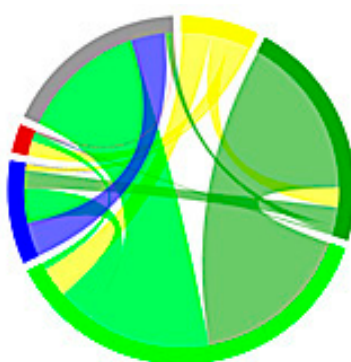

2010-2015

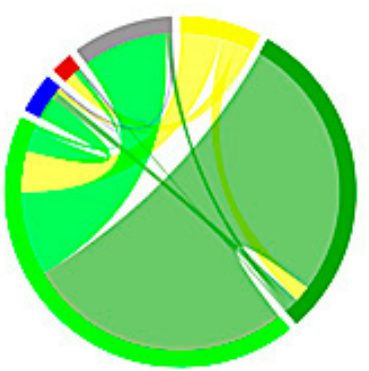

$1990-2015$

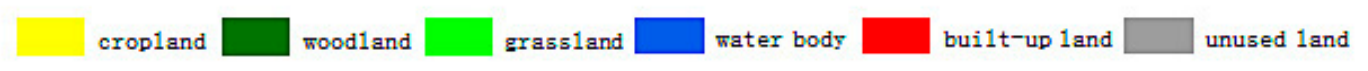

Figure 3. Land use change during different periods.

\subsubsection{Climate Change Analysis}

The change rates of the annual mean temperature and annual total precipitation in the Hengduan Mountain region were $0.05^{\circ} \mathrm{C} \mathrm{yr}^{-1}$ and $-2.56 \mathrm{~mm} \mathrm{yr}^{-1}$, respectively. This indicated that the Hengduan Mountain region became warmer and dryer over the 25-year period. Climate change also exhibited significant spatial heterogeneity. From 1990 to 2015, the northern area of the Hengduan Mountain region became warmer and wetter, while most of the remaining areas became warmer and dryer (Figures 4 and 5). 


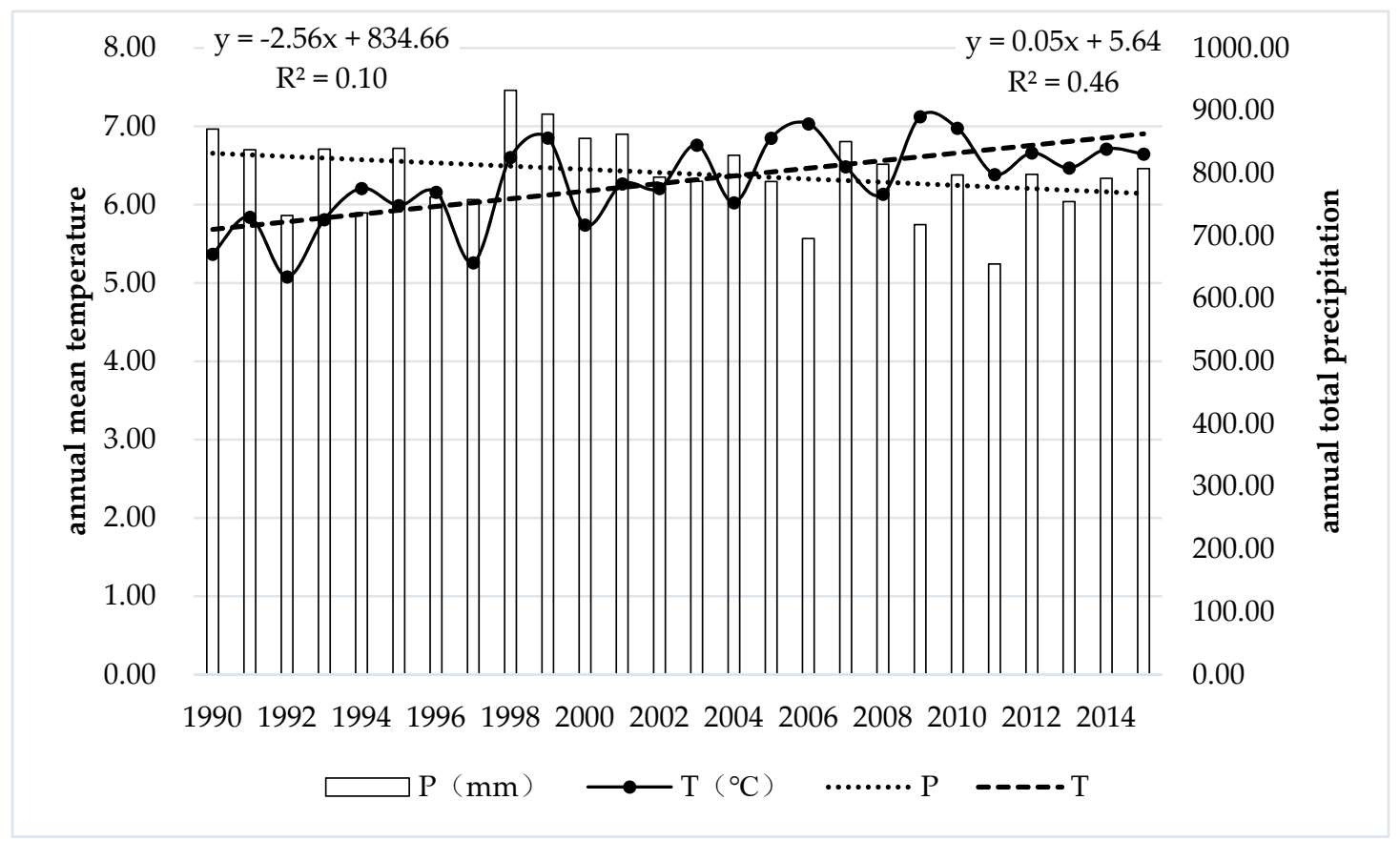

Figure 4. Changes in annual mean temperature $(\mathrm{T})$ and annual total precipitation $(\mathrm{P})$ in the Hengduan Mountain region during the period 1990-2015.
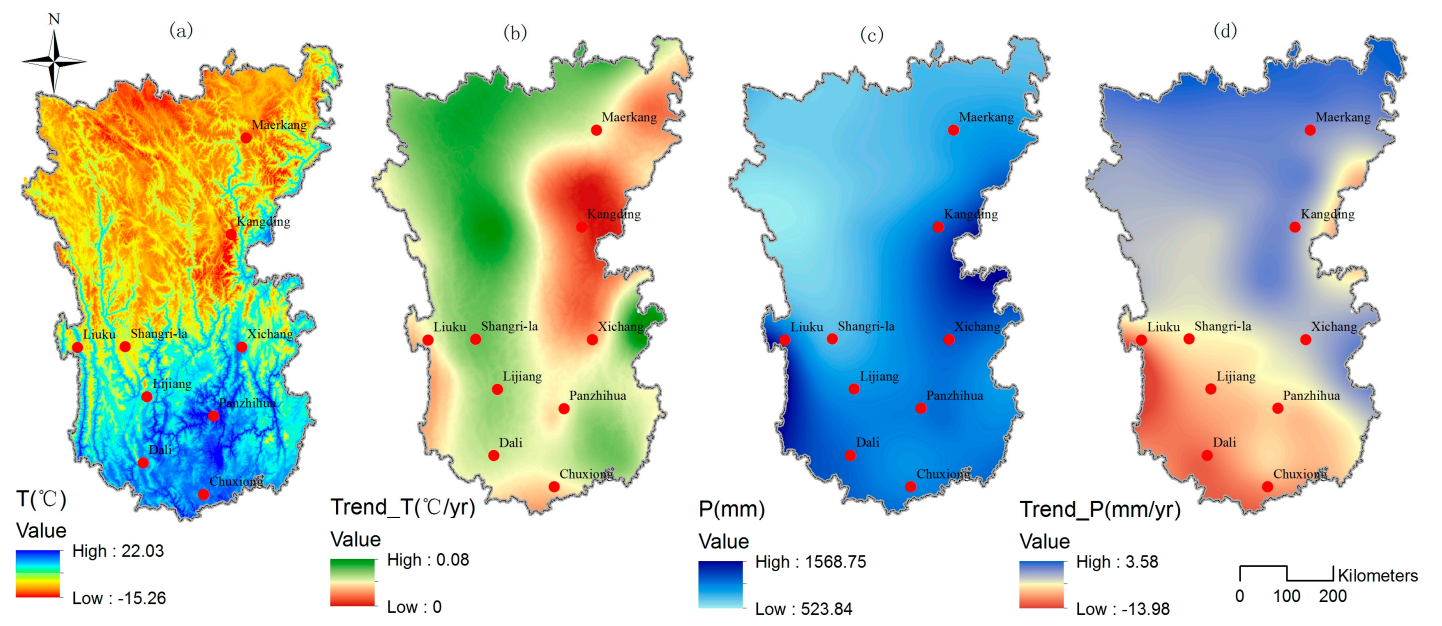

Figure 5. Spatial distribution of (a) annual mean temperature $(\mathrm{T}),(\mathbf{b})$ annual mean temperature change trend (Trend_T), (c) annual total precipitation $(\mathrm{P})$, and (d) annual total precipitation change trend (Trend_P) from 1990 to 2015.

\subsection{Assessment, Validation, and Spatio-Temporal Heterogeneity of Water Yield and Soil Erosion}

The water yield in 1990, 2000, 2010, and 2015 was $412.04 \mathrm{~mm}, 467.36 \mathrm{~mm}, 377.76 \mathrm{~mm}$, and $405.62 \mathrm{~mm}$, respectively, while the soil erosion rates were $28.61 \mathrm{t} \mathrm{ha}^{-1} \mathrm{yr}^{-1}, 31.23 \mathrm{t} \mathrm{ha}^{-1} \mathrm{yr}^{-1}, 24.77$ $\mathrm{t} \mathrm{ha}^{-1} \mathrm{yr}^{-1}$, and $25.86 \mathrm{t} \mathrm{ha}^{-1} \mathrm{yr}^{-1}$ in 1990, 2000, 2010, and 2015, respectively. The simulated water yield in the Hengduan Mountain region was similar to $421.07 \mathrm{~mm}$ of the $10-\mathrm{km}$ resolution multi-year average surface runoff datasets. The simulation value of soil erosion was similar to $26.86 \mathrm{t} \mathrm{ha}^{-1} \mathrm{yr}^{-1}$ of Ge et al. (2014) and $27.31 \mathrm{tha}^{-1} \mathrm{yr}^{-1}$ of Ouyang et al. (2016) [44,45].

In general, the spatial distribution pattern of water yield and soil erosion had not changed from 1990 to 2015. The areas with high water yield were mainly distributed in the southwest and northeast regions. The areas with severe soil erosion $\left(>50 \mathrm{tha}^{-1} \mathrm{yr}^{-1}\right)$ were mainly located in the valleys of the Hengduan Mountain region [46] (Figure 6). 


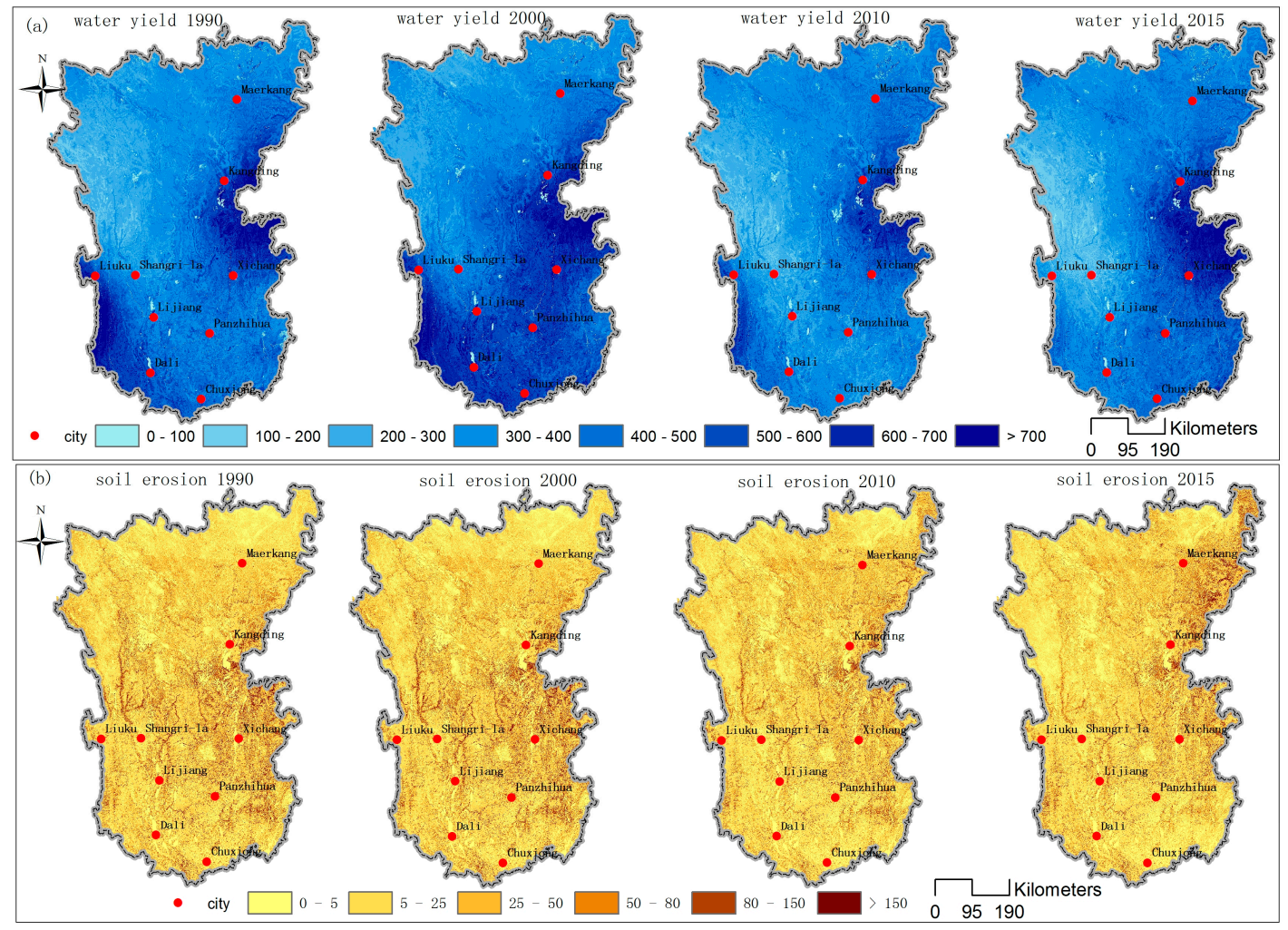

Figure 6. Assessment results of (a) water yield (mm) and (b) soil erosion ( $\left.\mathrm{t} \mathrm{ha}^{-1} \mathrm{yr}^{-1}\right)$.

\subsection{Changes in Water Yield and Soil Erosion under Different Conditions}

Under the land use and climate change condition, the water yield in the Hengduan Mountain region decreased by $6.42 \mathrm{~mm}$, and the soil erosion decreased by $2.75 \mathrm{t} \mathrm{ha}^{-1} \mathrm{yr}^{-1}$ from 1990 to 2015 . There was significant spatial heterogeneity in the trends of water yield and soil erosion rates in different areas. The decreased water yield was mainly concentrated in the southwest and northeast regions of the Hengduan Mountain region, while the increased area was mainly distributed in the northwest and southeast. Soil erosion decreased in most areas except in the northeast Hengduan Mountain region. Water yield and soil erosion decreased only during the period 2000-2010 (Figure 7a, Figure 8).

Under the land use change condition, water yield decreased by $1.73 \mathrm{~mm}$, while soil erosion decreased by $0.43 \mathrm{t} \mathrm{ha}^{-1} \mathrm{yr}^{-1}$ in the Hengduan Mountain region from 1990 to 2015. For different periods, land use change led to a decreasing trend of both water yield and soil erosion from 1990 to 2010. The water yield and soil erosion increased only during the period 2010-2015 (Figure 7b, Figure 9).

From 1990 to 2015, the water yield and soil erosion rates decreased by $4.69 \mathrm{~mm}$ and $2.22 \mathrm{t} \mathrm{ha}^{-1} \mathrm{yr}^{-1}$ under the climate change condition, respectively. The increasing area of water yield was mainly concentrated in the northwest and southeast, while the decreasing area was mainly distributed in the south and southwest Hengduan Mountain region. Soil erosion decreased in most areas, and the increasing area was mainly concentrated in the northeast and parts of the southwest areas. For different periods, water yield and soil erosion decreased only during the period 2000-2010 (Figure 7c, Figure 10). 
(a) land use and climate change condition

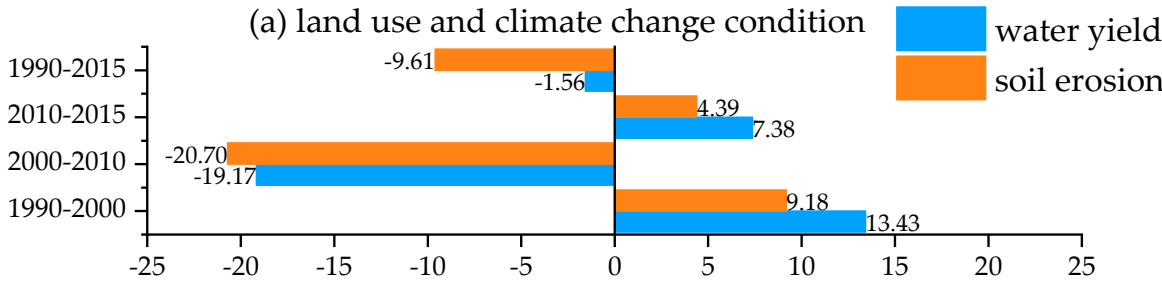

(b) land use change condition

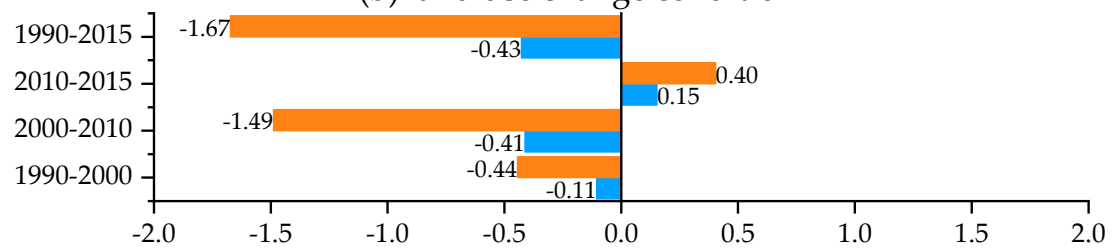

(c) climate change condition

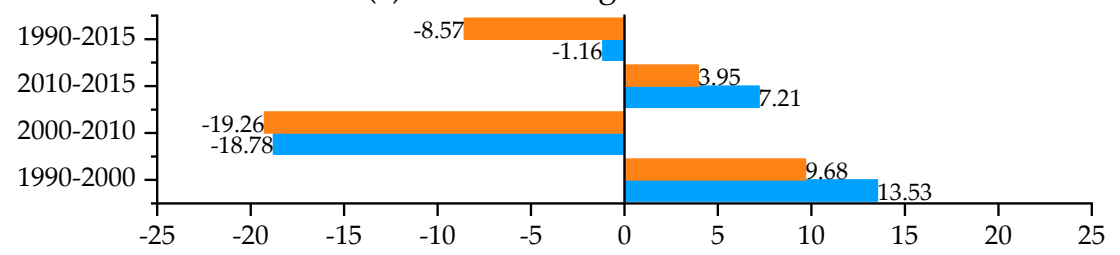

Figure 7. Change rates of water yield and soil erosion under different conditions in different periods (\%).

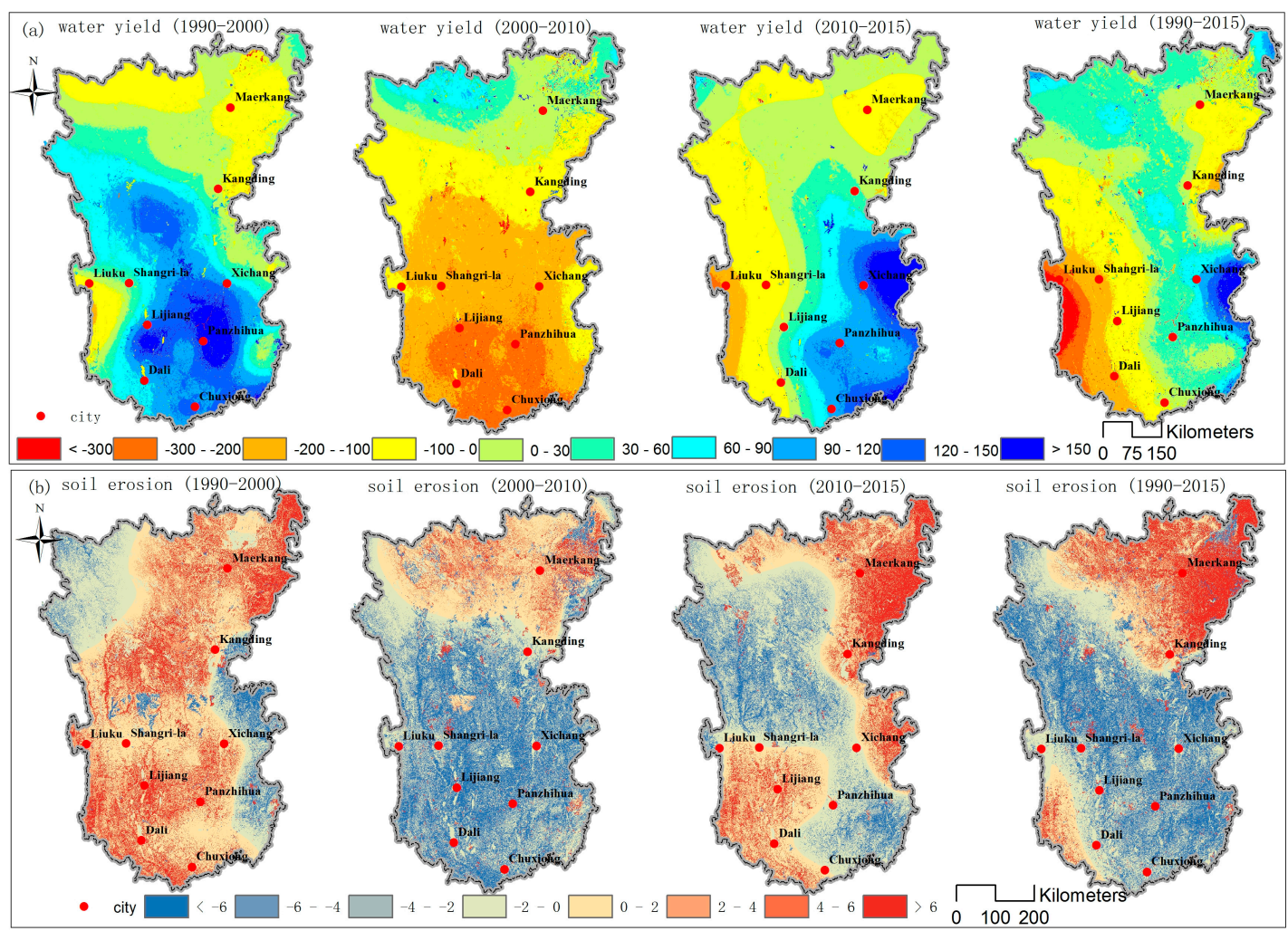

Figure 8. Spatial variation in (a) water yield (mm) and (b) soil erosion ( $\mathrm{t} \mathrm{ha}^{-1} \mathrm{yr}^{-1}$ ) under the land use and climate change condition. 


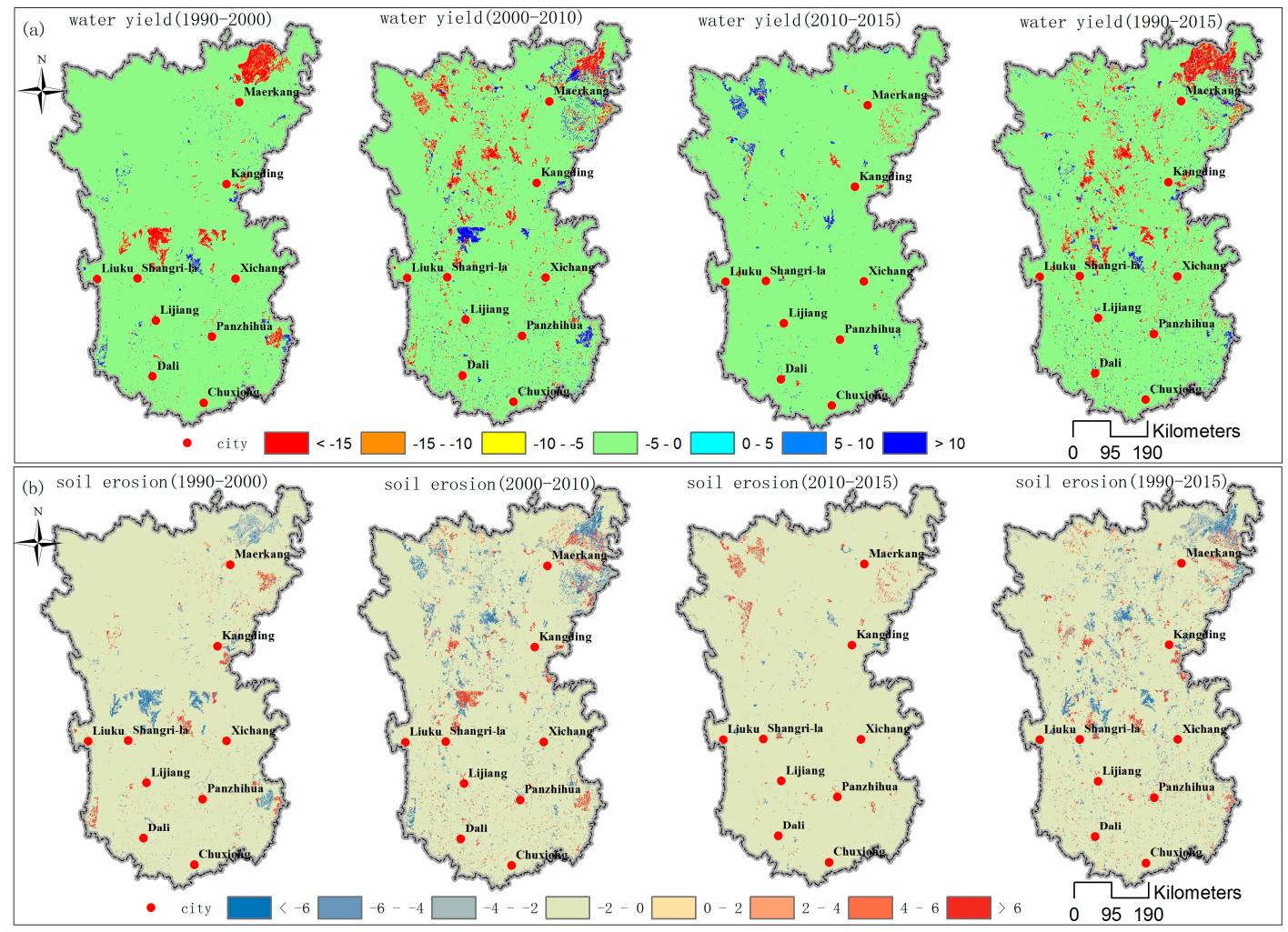

Figure 9. Spatial variation in (a) water yield ( $\mathrm{mm}$ ) and (b) soil erosion ( $\mathrm{t} \mathrm{ha}^{-1} \mathrm{yr}^{-1}$ ) under the land use change condition.

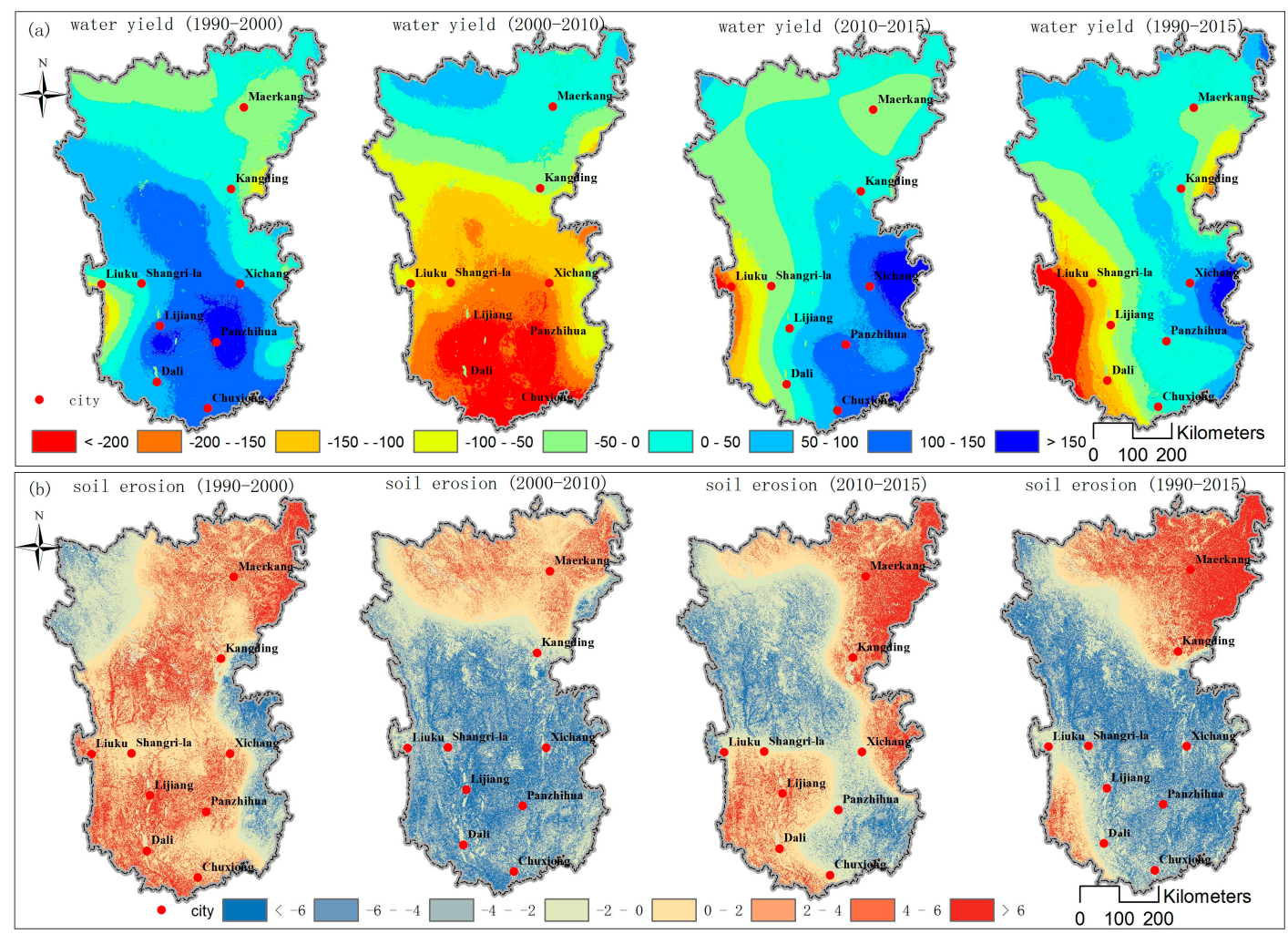

Figure 10. Spatial variation in (a) water yield ( $\mathrm{mm})$ and (b) soil erosion $\left(\mathrm{t} \mathrm{ha}^{-1} \mathrm{yr}^{-1}\right)$ under the climate change condition. 


\section{Discussion}

\subsection{Impacts of Land Use Change on Water Yield and Soil Erosion}

From 1990 to 2015, the area of land use conversion was $15761 \mathrm{~km}^{2}$, accounting for $3.52 \%$ of the total area. Because the main type of unused land in the Hengduan Mountain region was bare rock, we used bare rock instead of unused land for statistical analysis and did not consider the soil erosion. The current study determined the water and soil conservation capacity according to the changing trend of water yield and soil erosion rate during the land use conversion. The water yield capacity was: bare rock $>$ cropland $>$ grassland $>$ woodland, and the soil conservation capacity was: woodland $>$ grassland $>$ cropland (Table 2, Figure 11).

Table 2. Impacts of primary land use conversion on water yield and soil erosion (1990-2015).

\begin{tabular}{|c|c|c|c|c|c|}
\hline Land Use Change & Area $\left(\mathbf{k m}^{2}\right)$ & \multicolumn{2}{|c|}{ Water Yield } & \multicolumn{2}{|c|}{ Soil Erosion } \\
\hline Cropland to woodland & 753 & -181.94 & -1.37 & -103.85 & -7.82 \\
\hline Cropland to grassland & 1017 & -121.93 & -1.24 & -55.75 & -5.67 \\
\hline Woodland to cropland & 706 & 177.05 & 1.25 & 94.9 & 6.70 \\
\hline Grassland to cropland & 852 & 122.07 & 1.04 & 42.61 & 3.63 \\
\hline Grassland to woodland & 8429 & -54.93 & -4.63 & -30.75 & -25.92 \\
\hline Grassland to bare rock & 1160 & 130.34 & 1.51 & -51.21 & -5.94 \\
\hline Bare rock to grassland & 2196 & -101.09 & -2.22 & 49.18 & 10.80 \\
\hline
\end{tabular}

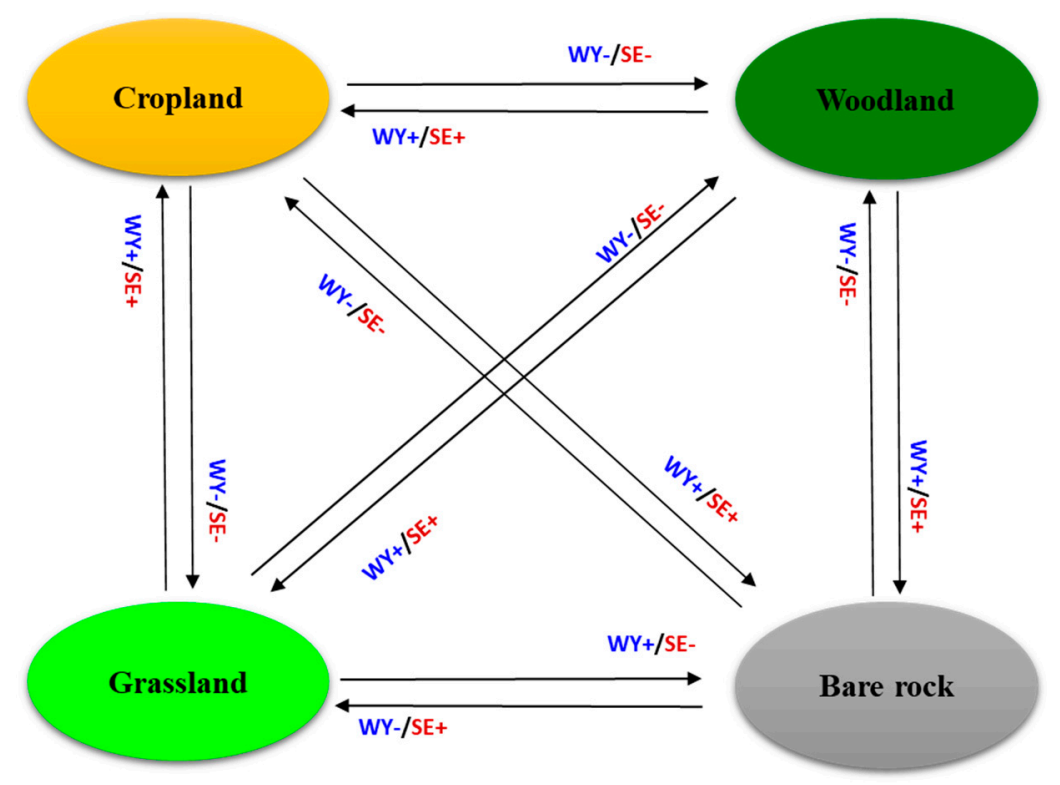

Figure 11. Change trends in water yield (WY) and soil erosion (SE) among major land use conversions.

Under the impact of land use change, water yield and soil erosion have decreased over the past 25 years. However, compared with the period 1990-2010, both water yield and soil erosion showed an increasing trend from 2010 to 2015, which was mainly caused by the conversion of woodland to grassland. Given the continuous implementation of ecological restoration projects in this region, this indicated that woodland degraded from 2010 to 2015, which may be related to forest harvesting, pests and diseases, and fire. Studies also found that, from 1998 to 2014, the role of human activities in improving the net primary productivity (NPP) of vegetation significantly decreased [47]. Thus, forest dynamic monitoring, such as that carried out by satellite [48] and drones [49], should be strengthened in the future so that the continuous benefits of ecological restoration projects can be achieved. 
The current study found that the implementation of ecological restoration projects in the Hengduan Mountain region can reduce soil erosion, but also inevitably reduce water yield, which poses a certain threat to agricultural irrigation and residential water in downstream areas. In the Loess Plateau region of China, studies have shown that vegetation productivity is already close to the maximum NPP, and continuing revegetation will seriously threaten the water security of human beings [50]. Moreover, influenced by lithology, topography, climate, and human activities, rocky desertification occurred in the Sichuan and Yunnan Provinces in an area of approximately $37,400 \mathrm{~km}^{2}$, accounting for approximately $26.66 \%$ of the exposed carbonate rock area and $4.32 \%$ of the total area [51]. Although precipitation is abundant in the Hengduan Mountain region, the loss of vegetation and soil would exacerbate infiltration, and the amount of water stored in the soil is low, resulting in insufficient soil moisture for vegetation growth [52]. Thus, future research on ecosystem service trade-offs [53,54] should be strengthened to find a balance between ecological and socio-economic demands to maximize the possibility of achieving the dual goals of ecological protection and economic development. In addition, due to the limitations imposed by topography, croplands are scarce in the Hengduan Mountain region. According to the requirements of the Sichuan, Yunnan, and Tibet Land Use Master Plan (2006-2020), we should strictly protect croplands and strengthen the construction of basic croplands in the future in order to ensure a stable and sustained food supply in this region. Therefore, ecological restoration by returning cropland to forest and grassland is neither permissible nor desirable at present.

\subsection{Impacts of Climate Change on Water Yield and Soil Erosion}

Temperature and precipitation are the most important climatic factors affecting regional ecosystem services [55,56]. From 1990 to 2015, the area that experienced a warming and drying trend was $307,618 \mathrm{~km}^{2}$, accounting for $68.87 \%$ of the total area, while the area that underwent a warmer and wetter trend was $139,019 \mathrm{~km}^{2}$, accounting for $31.13 \%$ of the total area. Without the impact of land use change, the water yield and soil erosion rates in the warming and drying trend area decreased by $28.05 \mathrm{~mm}$ and $5.99 \mathrm{t} \mathrm{ha}^{-1} \mathrm{yr}^{-1}$, respectively, while in the warming and wetting area, the water yield and soil erosion rates increased by $46.96 \mathrm{~mm}$ and $6.12 \mathrm{t} \mathrm{ha}^{-1} \mathrm{yr}^{-1}$, respectively (Table 3).

Table 3. Changes in water yield and soil erosion under the climate change condition from 1990 to 2015.

\begin{tabular}{|c|c|c|c|}
\hline Climate Change & Area $\left(\mathrm{km}^{2}\right)$ & Water Yield (mm) & $\begin{array}{l}\text { Soil Erosion Rates } \\
\left(\mathbf{t} \mathrm{ha}^{-1} \mathrm{yr}^{-1}\right)\end{array}$ \\
\hline Warming and drying & 307,618 & -28.05 & -5.99 \\
\hline Warming and wetting & 139,019 & 46.96 & 6.12 \\
\hline
\end{tabular}

During each period, the change trend for water yield and soil erosion was consistent with precipitation, which indicated that precipitation was the dominant factor affecting water yield and soil erosion. In addition, although the precipitation decreased from $976.04 \mathrm{~mm}$ to $847.45 \mathrm{~mm}$ from 1990 to 2015, rainfall erodibility increased from $3164.56 \mathrm{MJ} \mathrm{mm} \mathrm{ha}{ }^{-1} \mathrm{~h}^{-1} \mathrm{yr}^{-1}$ to $3922.89 \mathrm{MJ} \mathrm{mm} \mathrm{ha} \mathrm{m}^{-1} \mathrm{~h}^{-1} \mathrm{yr}^{-1}$. Therefore, soil erosion was not only affected by the amount of precipitation but it may also have been closely related to precipitation intensity, which is consistent with previous research findings [57,58].

Studies have shown that extreme drought, rainfall, and frequent flooding, which all pose a great threat to the ecological environment and the safety of people's lives and property, have significantly increased in the past few decades in most parts of southwest China $[59,60]$. In response to climate change, the construction of terraces and walls on hill slopes in southern Yunnan Province, such as the famous Hani terraces, provide a reference for the Hengduan Mountain region to prevent further soil erosion and realize sustainable agricultural development [61]. In addition, the eco-hydrological effects of land use change caused by human beings should be reviewed before the implementation of any ecological projects. Ideal vegetation for use in the ecological restoration of the Hengduan Mountain region would possess the characteristics of low water consumption and strong soil and water 
conservation capacity. For example, research has found that primary and old growth dark coniferous forests consume less water than other vegetation types in southwest China [62].

\subsection{Contribution of Land Use and Climate Change to Water Yield and Soil Erosion}

By comparing the changes in water yield and soil erosion under different conditions, we calculated the contribution of land use change and climate change to water yield and soil erosion from 1990 to 2015. For water yield, the contribution of land use and climate change was $26.94 \%$ and $73.06 \%$, while for soil erosion, the contribution of land use and climate change was $16.23 \%$ and $83.77 \%$, respectively. Therefore, climate change was the main driving force affecting the spatial and temporal changes in water yield and soil erosion from 1990 to 2015.

\subsection{Uncertainties}

The premise of separating ecosystem service impact factors is that different factors are independent of each other and have no interactions. But, in fact, there are complex interactions between land use and climate change that jointly drive global environmental change $[63,64]$. Therefore, the separation method may affect the accuracy of the contribution of land use and climate change to water yield and soil erosion. There are also uncertainties in the ecosystem service assessment. For water yield, the InVEST model does not distinguish between surface water, groundwater, and base flow, and does not consider the interaction between them [30]. The model greatly simplifies the consumption demand, and determining the demand through land use types may not fully reflect the distribution of water resources on different utilization patterns and time scales [8]. For soil erosion, there are few studies on cover management factor, $\mathrm{C}$, and erosion control practice factor, $\mathrm{P}$, in this region; the current study refers to the values of existing studies, which may also lead to uncertainty. This study only verified the assessment results of water yield and soil erosion with the help of existing research results. In the future, field test data or relevant data (such as evapotranspiration data and soil erosion survey data) could be used to verify the assessment results pixel by pixel in order to improve the reliability of the assessment results $[65,66]$.

\section{Conclusions}

This study proposed a framework for the separation of ecosystem service impact factors and quantified the contribution of land use and climate change to water yield and soil erosion in the Hengduan Mountain region. The main conclusions were:

(1) The total amount of water yield and soil erosion decreased under the impact of land use and climate change in the Hengduan Mountain region from 1990 to 2015, which indicates that the soil and water conservation capacity has increased over the past 25 years.

(2) Under the land use change condition, soil and water conservation capacity in the Hengduan Mountain region has decreased in the last five years. Dynamic monitoring of forests should be strengthened in the future so that ecological restoration projects can bring about continuous benefits.

(3) Climate change has played a decisive role in the change of water yield and soil erosion in the Hengduan Mountain region. Precipitation was the main factor affecting water yield and soil erosion, and soil erosion was not only affected by the amount of precipitation, but it was also closely related to precipitation intensity.

(4) The contribution of land use and climate change to water yield was $26.94 \%$ and $73.06 \%$, respectively, while for soil erosion, the contribution of land use and climate change was $16.23 \%$ and $83.77 \%$, respectively.

Author Contributions: E.D. conceived the study. L.Y. analyzed the results and wrote the manuscript. Y.W., L.M., and M.T. assisted with data processing. All authors have read and agreed to the published version of the manuscript. 
Funding: This research has no external funding.

Acknowledgments: This research was funded by the National Key R\&D Program of China (Grant No. 2017YFC1502903, 2018YFC1508805), the National Natural Science Foundation of China (Grant No. 41530749), and the Strategic Priority Research Program of Chinese Academy of Sciences (Grant No. XDA19040304).

Conflicts of Interest: The authors declare no conflict of interest.

\section{References}

1. Fu, B.J.; Zhou, G.Y.; Bai, Y.F.; Song, C.C.; Liu, J.Y.; Zhang, H.Y.; Lü, Y.H.; Zheng, H.; Xie, G.D. The main terrestrial ecosystem services and ecological security in China. Adv. Earth Sci. 2009, 6, 572-575.

2. Lawler, J.J.; Lewis, D.J.; Nelson, E.; Plantinga, A.J.; Polasky, S.; Withey, J.C.; Helmers, D.P.; Martinuzzi, S.; Pennington, D.; Radeloff, V.C. Projected land-use change impacts on ecosystem services in the United States. Proc. Natl. Acad. Sci. USA 2014, 111, 7492-7497. [CrossRef] [PubMed]

3. Thom, D.; Seidl, R. Natural disturbance impacts on ecosystem services and biodiversity in temperate and boreal forests. Biol. Rev. 2016, 91, 760-781. [CrossRef] [PubMed]

4. MA. Ecosystems and Human Well-Being; Island Press: Washington, DC, USA, 2005; Volume 5.

5. Liu, Y.; Bi, J.; Lv, J. Future impacts of climate change and land use on multiple ecosystem services in a rapidly urbanizing agricultural basin, China. Sustainability 2018, 10, 4575. [CrossRef]

6. Fu, Q.; Li, B.; Hou, Y.; Xu, B.; Zhang, X.S. Effects of land use and climate change on ecosystem services in Central Asia's arid regions: A case study in Altay Prefecture, China. Sci. Total Environ. 2017, 607-608, 633-646. [CrossRef]

7. Zhao, W.W.; Liu, Y.; Feng, Q.; Wang, Y.P.; Yang, S.Q. Ecosystem services for coupled human and environment systems. Prog. Geog. 2018, 37, 139-151.

8. Su, C.H.; Fu, B.J. Evolution of ecosystem services in the Chinese Loess Plateau under climatic and land use changes. Glob. Planet. Change. 2013, 101, 119-128. [CrossRef]

9. Yue, D.X.; Du, J.; Gong, J.; Jiang, T.C.; Zhang, J.J.; Guo, J.J. Dynamic analysis of farmland ecosystem service value and multiple regression analysis of the influence factors in Minqin Oasis. Acta Ecol. Sin. 2011, 31, 2567-2575.

10. Caputo, J.; Beier, C.M.; Groffman, P.M.; Burns, D.A.; Beall, F.D.; Hazlett, P.W.; Yorks, T.E. Effects of harvesting forest biomass on water and climate regulation services: A synthesis of long-term ecosystem experiments in eastern North America. Ecosystems 2016, 19, 271-283. [CrossRef]

11. Sanchez-Canales, M.; Lopez-Benito, A.; Acuna, V.; Ziv, G.; Hamel, P.; Chaplin-Kramer, R.; Elorza, F.J. Sensitivity analysis of a sediment dynamics model applied in a Mediterranean river basin: Global change and management implications. Sci. Total Environ. 2015, 502, 602-610. [CrossRef]

12. Wang, H.; Gao, J.B.; Hou, W.J. Quantitative attribution analysis of soil erosion in different geomorphological types in karst areas: Based on the geodetector method. J. Geogr. Sci. 2019, 29, 271-286. [CrossRef]

13. Wang, J.; Brown, D.G.; Chen, J.Q. Drivers of the dynamics in net primary productivity across ecological zones on the Mongolian Plateau. Landsc. Ecol. 2013, 28, 725-739. [CrossRef]

14. Li, A.; Wu, J.G.; Huang, J.H. Distinguishing between human-induced and climate-driven vegetation changes: A critical application of RESTREND in inner Mongolia. Landsc. Ecol. 2012, 27, 969-982. [CrossRef]

15. Huang, K.; Zhang, Y.J.; Zhu, J.T.; Liu, Y.J.; Zu, J.X.; Zhang, J. The influences of climate change and human activities on vegetation dynamics in the Qinghai-Tibet Plateau. Remote. Sens. 2016, 8, 876. [CrossRef]

16. Chen, H.; Zhu, Q.; Peng, C.; Wu, N.; Wang, Y.; Fang, X.; Gao, Y.; Zhu, D.; Yang, G.; Tian, J.; et al. The impacts of climate change and human activities on biogeochemical cycles on the Qinghai-Tibetan Plateau. Glob. Chang. Biol. 2013, 19, 2940-2955. [CrossRef]

17. Fryrear, D.; Sutherland, P.; Davis, G.; Hardee, G.; Dollar, M. Wind erosion estimates with RWEQ and WEQ. In Proceedings of the Conference Sustaining the Global Farm, 10th International Soil Conservation Organization Meeting; Purdue University: West Lafayette, IN, USA, 1999; pp. 760-765.

18. Chen, D.; Li, J.; Zhou, Z.; Liu, Y.; Li, T.; Liu, J. Simulating and mapping the spatial and seasonal effects of future climate and land-use changes on ecosystem services in the Yanhe watershed, China. Environ. Sci. Pollut. Res. Int. 2018, 25, 1115-1131. [CrossRef] 
19. Krkoška Lorencová, E.; Harmáčková, Z.V.; Landová, L.; Pártl, A.; Vačkář, D. Assessing impact of land use and climate change on regulating ecosystem services in the Czech Republic. Ecos. Health Sust. 2016, 2, 1-12. [CrossRef]

20. Ostberg, S.; Schaphoff, S.; Lucht, W.; Gerten, D. Three centuries of dual pressure from land use and climate change on the biosphere. Environ. Res. Lett. 2015, 10, 044011. [CrossRef]

21. Wang, R.Y.; Kalin, L.; Kuang, W.H.; Tian, H.Q. Individual and combined effects of land use/cover and climate change on Wolf Bay watershed streamflow in southern Alabama. HyPr 2014, 28, 5530-5546. [CrossRef]

22. Wang, Y.Z.; Zhang, J.Z.; Li, X.Y.; Cao, L.Y. Hydrological characteristics of the Hengduan Mountain area. Hydrology 1983, 3, 41-48.

23. Rao, E.M.; Xiao, Y.; Ouyang, Z.Y.; Zheng, H. Changes in ecosystem service of soil conservation between 2000 and 2010 and its driving factors in southwestern China. Chin. Geogr. Sci. 2016, 26, 165-173. [CrossRef]

24. Liu, S.P.; Chen, D.Q.; Duan, X.B.; Qiu, S.L.; Huang, M.G. Monitoring of the four famous Chinese carps resources in the middle and upper reaches of the Yangtze River. Resour. Environ. Yangtze Basin 2004, 13, 183-186.

25. Zhou, Z.C.; Gan, Z.T.; Shangguan, Z.P.; Dong, Z.B. China's Grain for Green Program has reduced soil erosion in the upper reaches of the Yangtze River and the middle reaches of the Yellow River. Int. J. Sustain. Dev. World 2009, 16, 234-239. [CrossRef]

26. Zheng, D.; Yang, Q.Y. Some problems of natural regionalization in Hengduan mountain area. J. Mount. Res. 1987, 5, 7-13.

27. Li, Z.X.; He, Y.Q.; Xin, H.J.; Wang, C.F.; Jia, W.X.; Zhang, W.; Liu, J. Spatio-temporal variations of temperature and precipitation in Mts. Hengduan Region during 1960-2008. J. Geogr. Sci. 2010, 27, 980-986.

28. Liu, J.Y.; Kuang, W.H.; Zhang, Z.X.; Xu, X.L.; Qin, Y.W.; Ning, J.; Zhou, W.C.; Zhang, S.W.; Li, R.D.; Yan, C.Z. Spatiotemporal characteristics, patterns, and causes of land-use changes in China since the late 1980s. J. Geogr. Sci. 2014, 24, 195-210. [CrossRef]

29. Hutchinson, M.F.; Xu, T. Anusplin Version 4.2 User Guide; Centre for Resource and Environmental Studies, The Australian National University: Canberra, Australia, 2004; Volume 54.

30. Sharp, R.; Tallis, H.T.; Ricketts, T.; Guerry, A.D.; Wood, S.A.; Chaplin-Kramer, R.; Nelson, E.; Ennaanay, D.; Wolny, S.; Olwero, N.; et al. InVEST User's Guide. 2014. Available online: http://data.naturalcapitalproject. org/nightly-build/invest-users-guide/html/ (accessed on 13 July 2016).

31. Renard, K.G.; Foster, G.R.; Weesies, G.A.; Mccool, D.K.; Yoder, D.C. Predicting Soil Erosion by Water: A Guide to Conservation Planning with the Revised Universal Soil Loss Equation (RUSLE); United States Department of Agriculture: Washington, DC, USA, 1997.

32. Zhou, W.; Liu, G.; Pan, J.; Feng, X. Distribution of available soil water capacity in China. J. Geogr. Sci. 2005, 15, 3-12. [CrossRef]

33. Droogers, P.; Allen, R.G. Estimating reference evapotranspiration under inaccurate data conditions. Irrig. Drain. Syst. 2002, 16, 33-45. [CrossRef]

34. Hu, Q.F.; Yang, D.W.; Wang, Y.T.; Yang, H.B. Global calibration of Hargreaves equation and its applicability in China. Adv. Water Sci. 2011, 22, 160-167.

35. Wischmeier, W.H. Predicting rainfall erosion losses from cropland east of the Rocky Mountain. In Agricultural Handbook; Government Printing Office: Washington, DC, USA, 1965; p. 47.

36. Arnoldus, H.M.J.; Boodt, M.D.; Gabriels, D. An approximation of the rainfall factor in the Universal Soil Loss Equation. In Assessment of Erosion; De Boodt, M., Gabriels, D., Eds.; John Wiley and Sons: New York, NY, USA, 1980; pp. 127-132.

37. Williams, J.; Jones, C.; Kiniry, J.; Spanel, D.A. The EPIC crop growth model. Trans. ASAE 1989, 32, $497-511$. [CrossRef]

38. McCool, D.; Brown, L.; Foster, G.; Mutchler, C.; Meyer, L. Revised slope steepness factor for the Universal Soil Loss Equation. Trans. ASAE 1987, 30, 1387-1396. [CrossRef]

39. Zhang, H.; Yang, Q.; Li, R.; Liu, Q.; Moore, D.; He, P.; Ritsema, C.J.; Geissen, V. Extension of a GIS procedure for calculating the RUSLE equation LS factor. Comput. Geosci. 2013, 52, 177-188. [CrossRef]

40. Renard, K.G.; Foster, G.R.; Weesies, G.A. Predicting soil erosion by water: A guide to conservation planning with the Revised Universal Soil Loss Equation (RUSLE). In Agricultural Handbook No. 703; U.S. Department of Agriculture, U.S.Government Printing Office: Washington, DC, USA, 1997; p. 404. 
41. Fu, B.; Liu, Y.; Lü, Y.; He, C.; Zeng, Y.; Wu, B. Assessing the soil erosion control service of ecosystem change in the Loess Plateau of China. Ecol. Complex. 2011, 8, 284-293. [CrossRef]

42. Xiao, L.; Yang, X.; Chen, S.; Cai, H. An assessment of erosivity distribution and its influence on the effectiveness of land use conversion for reducing soil erosion in Jiangxi, China. Catena 2015, 125, 50-60. [CrossRef]

43. Wang, D.B.; Hejazi, M. Quantifying the relative contribution of the climate and direct human impacts on mean annual streamflow in the contiguous United States. Water Resour. Res. 2011, 47, 1-16. [CrossRef]

44. Ouyang, Z.Y.; Zheng, H.; Xiao, Y.; Polasky, S.; Liu, J.; Xu, W.; Wang, Q.; Zhang, L.; Xiao, Y.; Rao, E. Improvements in ecosystem services from investments in natural capital. Science 2016, 352, 1455-1459. [CrossRef]

45. Ge, Y.; Cui, P.; Lin, Y.; Zhuang, J.; Jia, S. Soil erosion evaluation and prediction approach using 137Cs, RS, and GIS in the Xiaojiang River basin of China. J. Remote Sens. 2014, 18, 887-901.

46. Ministry of Water Resources of the People's Republic of China. Standards for Classification and Gradation of Soil Erosion, SL 190-96; China Hydroelectricity Press: Beijing, China, 2008.

47. Chen, T.; Peng, L.; Liu, S.; Wang, Q. Spatio-temporal pattern of net primary productivity in Hengduan Mountains area, China: Impacts of climate change and human activities. Chin. Geogr. Sci. 2017, 27, 948-962. [CrossRef]

48. Reiche, J.; Lucas, R.; Mitchell, A.L.; Verbesselt, J.; Hoekman, D.H.; Haarpaintner, J.; Kellndorfer, J.M.; Rosenqvist, A.; Lehmann, E.A.; Woodcock, C.E. Combining satellite data for better tropical forest monitoring. Nat. Clim. Chang. 2016, 6, 120. [CrossRef]

49. Zhang, J.; Hu, J.; Lian, J.; Fan, Z.; Ouyang, X.; Ye, W. Seeing the forest from drones: Testing the potential of lightweight drones as a tool for long-term forest monitoring. Biol. Conserv. 2016, 198, 60-69. [CrossRef]

50. Feng, X.; Fu, B.; Piao, S.; Wang, S.; Ciais, P.; Zeng, Z.; Lü, Y.; Zeng, Y.; Li, Y.; Jiang, X.; et al. Revegetation in China's Loess Plateau is approaching sustainable water resource limits. Nat. Clim. Chang. 2016, 6, 1019-1022. [CrossRef]

51. Jiang, Z.; Lian, Y.; Qin, X. Rocky desertification in Southwest China: Impacts, causes, and restoration. Earth-Sci. Rev. 2014, 132, 1-12. [CrossRef]

52. Wang, S.J.; Liu, Q.M.; Zhang, D.F. Karst rocky desertification in southwestern China: Geomorphology, land use, impact and rehabilitation. Land Degrad. Dev. 2004, 15, 115-121. [CrossRef]

53. Goldstein, J.H.; Giorgio, C.; Thomas Kaeo, D.; Driss, E.; Neil, H.; Guillermo, M.; Stephen, P.; Stacie, W.; Daily, G.C. Integrating ecosystem-service tradeoffs into land-use decisions. Proc. Natl. Acad. Sci. USA 2012, 109, 7565-7570. [CrossRef] [PubMed]

54. Dai, E.F.; Wang, X.l.; Zhu, J.J.; Xi, W.M. Quantifying ecosystem service trade-offs for plantation forest management to benefit provisioning and regulating services. Ecol. Evol. 2017, 7, 7807-7821. [CrossRef]

55. Stonefelt, M.D.; Fontaine, T.A.; Hotchkiss, R.H. Impacts of climate change on water yield in the Upper Wind River Basin. J. Am. Water Resour. Assos. 2010, 36, 321-336. [CrossRef]

56. O'Neal, M.R.; Nearing, M.A.; Vining, R.C.; Southworth, J.; Pfeifer, R.A.J.C. Climate change impacts on soil erosion in Midwest United States with changes in crop management. Catena 2005, 61, 165-184. [CrossRef]

57. Michael, A.; Schmidt, J.; Enke, W.; Deutschländer, T.; Malitz, G.J.C. Impact of expected increase in precipitation intensities on soil loss-results of comparative model simulations. Catena 2005, 61, 155-164. [CrossRef]

58. Nearing, M.A.; Jetten, V.; Baffaut, C.; Cerdan, O.; Couturier, A.; Hernandez, M.; Bissonnais, Y.L.; Nichols, M.H.; Nunes, J.P.; Renschler, C.S. Modeling response of soil erosion and runoff to changes in precipitation and cover. Catena 2005, 61, 131-154. [CrossRef]

59. Su, B.; Xiao, B.; Zhu, D.; Jiang, T. Trends in frequency of precipitation extremes in the Yangtze River basin, China: 1960-2003. Hydrolog. Sci. J. 2005, 50, 479-492.

60. Zhang, M.; Jinyun, H.E.; Wang, B.; Wang, S.; Shanshan, L.I.; Liu, W.; Xuening, M.A. Extreme drought changes in Southwest China from 1960 to 2009. J. Geogr. Sci. 2013, 23, 3-16. [CrossRef]

61. Jiao, Y.; Li, X.; Liang, L.; Takeuchi, K.; Okuro, T.; Zhang, D.; Sun, L. Indigenous ecological knowledge and natural resource management in the cultural landscape of China's Hani Terraces. Ecol. Res. 2012, 27, 247-263. [CrossRef]

62. Zhang, Y.; Liu, S.; Gu, F. The impact of forest vegetation change on water yield in the subalpine region of southwestern China. Acta Ecol. Sin. 2011, 31, 7601-7608.

63. Dale, V.H. The relationship between land-use change and climate change. Ecol. Appl. 1997, 7, 753-769. [CrossRef] 
64. Mendelsohn, R.; Dinar, A. Land use and climate change interactions. Annu. Rev. Resour. Econ. 2009, 1, 309-332. [CrossRef]

65. Jung, M.; Reichstein, M.; Ciais, P.; Seneviratne, S.I.; Sheffield, J.; Goulden, M.L.; Bonan, G.; Cescatti, A.; Chen, J.; Jeu, R.; et al. Recent decline in the global land evapotranspiration trend due to limited moisture supply. Nature 2010, 467, 951-954. [CrossRef]

66. Yue, Y.; Ni, J.; Ciais, P.; Piao, S.; Wang, T.; Huang, M.; Borthwick, A.G.L.; Li, T.; Wang, Y.; Chappell, A.; et al. Lateral transport of soil carbon and land-Atmosphere $\mathrm{CO}_{2}$ flux induced by water erosion in China. Proc. Natl. Acad. Sci. USA 2016, 113, 6617-6622. [CrossRef]

(C) 2020 by the authors. Licensee MDPI, Basel, Switzerland. This article is an open access article distributed under the terms and conditions of the Creative Commons Attribution (CC BY) license (http://creativecommons.org/licenses/by/4.0/). 